\title{
THE CONTRIBUTION OF TEACHERS' PEDAGOGICAL COMPETENCE TOWARD THE EFFECTIVENESS OF TEACHING OF ENGLISH AT MTSN BALANG-BALANG
}

\author{
Julkifli Hidayat Ada \\ Julkiflihidayatada@gmail.com \\ St. Azisah \\ sitiazisah@yahoo.com \\ Uiniversitas Islam Negeri Alauddin Makassar
}

\begin{abstract}
This research aims at finding the Contribution of Teachers' Pedagogical Competence toward the Effectiveness of Teaching of English at MTsN Balang-Balang. This research used the qualitative descriptive research, that is the researcher observe the teaching and learning process and interact with the teacher by interview and observation. The researcher found that the contribution of teachers pedagogy competence toward the effectiveness of teaching of English, seems the teacher have made serious effort in conducting the teaching and learning to make more effective in teaching of English in the class. This contribution seen from how they organize the learning from arranged the teaching plan, teaching and learning process, and assessment. The teachers were also able to motivate the students to attend the class, induce the students to learn the material as well as explain the material clearly so that the students could comprehend it easily. Furthermore, the students were also active in asking and answering questions both from the teacher. In the section of discussion, the students were also able to conclude the materials taught during the teaching and learning process. It means that teacher's pedagogy competence could improve students' motivation to learn.
\end{abstract}

Keyword:

\section{INTRODUCTION}

$\mathrm{T}$ oday the profession of teachers occupies an important position, because preparing the qualification of human resources. A teacher carries a big responsibility in his/her classroom. One reason is that all students depend on his/her. Everything the teacher says will have an impact on the students. If a teacher feels joy of feels anger, it will be spreaded out among students. In this case, the attitudes of the teacher gets contagious. In a society, from the most backward to the most advanced, the teacher plays an important role as, almost without exception, the builders of prospective society members (Popham, WJ \& Baker, EL 2005). It is partly true because teachers are the key players in classroom instructional activities that affect the success of students. Teachers' pedagogical competence is the ability to manage learning, which includes planning, implementation and evaluation of learning outcomes of learners. These competencies should be owned by every teacher in order to achieve success in learning and teaching .

They will be professional as they deals with the system approach of instruction including working with the outcome-based curriculum, diagnosis of cognitive affective readiness style and interest, program design, classroom management, instruction and 
learning, as well as evaluation and feedback (Snyder and Anderson, 1986). Teachers also contribute to the high effectiveness of schools as they are parts of the school resources.

Caldwell and Spinks (1991:27) says that "school resources becomes one of six most important contributors to the highly effective schools among school climate, leadership, decision makings, and outcomes". One of the challenges that teachers face is the fulfillment of their potential. It is believe that many teachers fail to fullfil their potential, not because of they do not know the subject matter, but because they do not understand students or classrooms".

Lexically teacher is defined as "people whose jobs or occupation is teaching." In a simple term, teacher is the one who gives knowledge to students (Djamaroh, 2008). Meanwhile, the Indonesia Republic Law No. 20, 2003 concerning National Education system confirms that: educators are professionals who are in charge of planning and implementing the learning process, assessing learning outcomes, coaching, training, and conducting research as well as community service, particularly for educators at the higher education. That is why, teachers should have competences in playing their roles in educating their students.

In the act of the Republic of Indonesia Number 14 years 2005 states that teachers are professional educators with the primary task of educating, teaching, guiding, directing, train, assess, and evaluate students on early childhood education, formal education, basic education, and secondary education.

Considering the above discussion, it is important for teacher to be competent. That the contribution of pedagogical competence are very important to make learning more effective. So from this circumstance, derive from my experience when the researcher did PPL (Teaching Practice), the researcher observed that so many teachers who have many drawbacks when they were teaching that related with their competences.

Based on the issue discussed previous, the problem statements of this research are formulated as follows:

How is the contribution of teachers' pedagogical competences contribute to the effectiveness of teaching of English at MTsN Balang-Balang?

\section{REVIEW LITERATURE}

\section{Teachers' Competencies}

Teachers need to improve knowledge and skills to enhance, improve and explore their teaching practices. Many of the studies on competencies of teachers focus on the teaching role of teachers in the classroom rather than teachers' competencies. Teachers' competencies have been broadening with respect to reform studies in education, development of teacher education, scientific results of educational science and other fields. 
Kress pointed out that " the previous era had required an education for stability, the coming era requires an education for instability" (Kress, 2000 :133). Kress' ideas can explain why teachers' professional development should be redefined for sustainability. The aims of education change very quickly depending on the demands of the era requiring more capability. These demands directly affect educational system. Teachers are responsible for operating educational system and they need strong and efficient professional competencies. Teachers' competencies must be reviewed so that teachers' competencies should be redefined depending on the development of the whole life of human and education.

Competencies are defined as "the set of knowledge, skills, and experience necessary for future, which manifests in activities" (Katane et. al. 44). Gupta (4) define competencies as "knowledge, skills, attitudes, values, motivations and beliefs people need in order to be successful in a job." The common understanding related to teachers' competencies is divided into three main areas as field competencies, pedagogical competencies and cultural competencies. Teachers' professional competencies can be composed of different dimensions other than the three main areas (Bulajeva 41; Bridge; Hansen 169; James et al. 113; Stoffels 544; Selvi, The English language 5).

Selvi (The English language 4) carried out a research regarding the professional competencies of English Language Teachers. The Conventional Delphi Technique was applied in order to constitute the competencies of new teachers based on the teachers' and teacher educators' views. Delphi process was completed after third rounds collecting the responses from the experts and Delphi round continued until the group consensus was achieved. The results of this study indicated that teachers' professional competencies were composed of four main subgroups such as Curriculum Competencies, Lifelong Learning Competencies, Social-Cultural Competencies and Emotional Competencies. The results showed that teachers' competencies must be discussed from a different point of view. In this context, the literature about teachers' competencies was analyzed and the new competency areas constituted as seen below concerning the teachers' competencies were tried to redefine depending on different dimensions of teachers' professional competencies. The main feature of teachers' professional competencies can be explained in a way displayed in Figure 1. First of all, these competencies were explained very briefly and only the curriculum competencies were discussed in detail among the other competencies in this paper.

- Field Competencies

- Research Competencies

- Curriculum Competencies

- Lifelong Learning Competencies

- Social-Cultural Competencies

- Emotional Competencies

- Communication Competencies

- Information and Communication Technologies (ICT) Competencies 


\section{- Environmental Competencies}

According to Law No 14, 2005 about Teachers and Lecturers, Article 10 paragraph (1), teacher competency includes pedagogical competency, personal competency, social competency, and professional competency that is acquired through professional education. Pedagogical competence is "the ability of learners to manage learning". This competency can be seen from the ability to plan teaching and learning program, the ability to execute the interaction or manage the learning process, and the ability to make an assessment. 'Teachers' personal competency as educators is their main task in teaching. They are to have good personal characteristics highly influencing the success of people development. Steady personality of the teacher will well exemplify learners and community. Therefore, teachers will perform as a figure necessarily followed in advice, words, and commands. Teachers' personality is an important factors for the success of students learning.

\section{Pedagogical Competencies}

According to Subroto (1983), factors attached to teachers affecting the teaching and learning programs are personality, material mastery, classroom management, ways of teacher talk, ways of creating classroom situation, concerns for individual principles, openness, collaboration, responsiveness to innovation, willingness and ability to carry out learning experiments. That teachers have the ability to manage learning well, teachers need to have professional skills to meet the 10 competencies of teachers, namely: 1. Mastering the materials, 2. Managing the teaching and learning programs, 3. Managing the class, 4. Using media or source, 5. Mastering the foundations of education, 6. Managing the teaching and learning interactions, 7. Assessing students' achievement for the benefit of lessons, 8. Knowing the functions of guidance and counseling services in schools, 9. Understanding the principles of learning, 10. Interpreting the results of educational research for teaching purposes (Subroto, 1983). Peadagogical Competence:

a. Teaching Plan Competency. Efforts made to empower teacher competency in this area were done by directing and enabling teachers to have the ability of (1) describing objectives, (2) selecting materials, (3) organizing materials,(4) determining learning methods and strategies, (5) determining learning sources, media, and tools,(6) designing assessment and evaluation tools, (7) determining assessment and evaluation technique, and (8) allocating time.

b. Learning and Teaching Process Competency: Improved Learning and Teaching Process. Competency were (1) opening lesson, (2) delivering materials, (3) using media and method, (4) using teaching media, (5) using communicative language, (6) motivating students (7) organizing activities, (8) interacting with students communicatively, (9) concluding lessons, (10) providing feedback (11) conducting assessment and evaluation, and (12) using time effectively. 
Julkifli Hidayat Ada \& St. Azisah, The Contribution of Teachers Pedagogical Competence Toward. .

c. Learning and Teaching Assessment and Evaluation Competency. The teacher empowerment in terms of this competency turned out to directed to the ability of: (1) choosing questions based on the level of difficulty, (2) selecting questions based on the level of differentiation, (3) repairing the problem is not valid, (4) checking the answer, (5) classifying the results of the assessment, (6) processing and analyzing. assessment results, (7) making interpretation of the trend assessment results, (8) determining the correlation problem based on the assessment results, (9) assessing to identify the level of variation in the results, (10) inferring from the results of the assessment clearly and logically, (11) arranging follow-up program assessment results, (12) classifying students, (13) identifying the need for follow-up assessment results, (14 ) carrying out follow-up, (15) evaluating the results of follow-up, and (16) analyzing the results of evaluation.

\section{Pedagogical Competence Indicator}

A professional teacher is a person who has the ability and expertise in the field of teacher or in other words he has educated and very well trained. Educated and trained not only gain formal education but also have to master a variety of strategies or in the techniques of teaching and learning activities and master the foundations as noted in the educational competence of teachers.

Competencies that must be owned by a teacher namely: professional competence, personality, pedagogical, and social. According to A. Fatah Yasin, pedagogic competence is the ability of an educator in managing the learning of students include:

a. The ability to understand the learners, with indicators between other: (1) Understanding the developmental characteristics of learners, such as understand the level of cognition of learners according to age; (2) Understanding the principles of personality development of students, as to recognize the personality types of learners, recognize stages of personality development of students, and others; (3) Be able to identify the provision of teaching early learners, recognize differences in the potential of students, and so forth.

b. The ability to create learning design, with indicators, among others: (1) Ability to plan the organization learning materials, such as being able to examine and describe the material listed in the curriculum, teaching materials are able to choose in accordance with the material, being able to use learning resources adequate, and others; (2) Ability to plan management learning, such as formulating learning objectives to achieved in accordance with the competence to be achieved, choose the type of strategy / learning methods are suitable, determine steps learning, determining how that can be used to motivate learners, determining forms questions will be presented to the students, and others; (3) Ability classroom management plan, such as a space arrangement sitting learners, allocate time, and others; (4) Capable planned use of the media and the means that can be used facilitate the achievement of competencies, and others; (5) Ability plan 
learning process valuation models, such as determine the form, procedure, and assessment tools.

c. The ability to implement the learning, with indicators such as: (1) Being able to apply the teaching of basic skills, such as open lessons, explained, the pattern of variation, asked, giving strengthening, and close the lesson; (2) Ability to apply various kind of model approaches, strategies/learning methods, such as active learning, learning portfolios, contextual learning and other; (3) Ability to master classes, such as activating participants learners in asking, able to answer and direct questions student, group work, self-employment, and others; (4) Capable measure the level of achievement of competence of learners during the process learning takes place.

d. Ability to evaluate learning outcomes, indicators among others: (1) Ability to design and implement assessment, such as understand the principles assessment, able to devise various learning evaluation instrument, capable of carrying out evaluation, and others; (2) capable of analyzing the results of assessment, such as capable of processing the results of evaluation of learning, able to recognize characteristics evaluation instruments; (3) Being able to utilize the results assessment for further improvement of the quality of learning, such as utilizing the results of the analysis in the process of evaluation instruments improvement of evaluation instruments, and able to provide feedback for improved planning, implementation and evaluation learning.

e. The ability to develop learners to actualize its potential, with indicators, among others: (1) Facilitate learners to develop academic potential, such as the channel potential academic learners according to their ability, capable directing and developing the academic potential of learners; (2) Capable of facilitating learners to develop potential non-academic, such as channeling the potential of non-academic participants students according to their abilities, able to direct and developing the potential of non-academic learners.

\section{Theoretical Framework}

Pedagogical competence

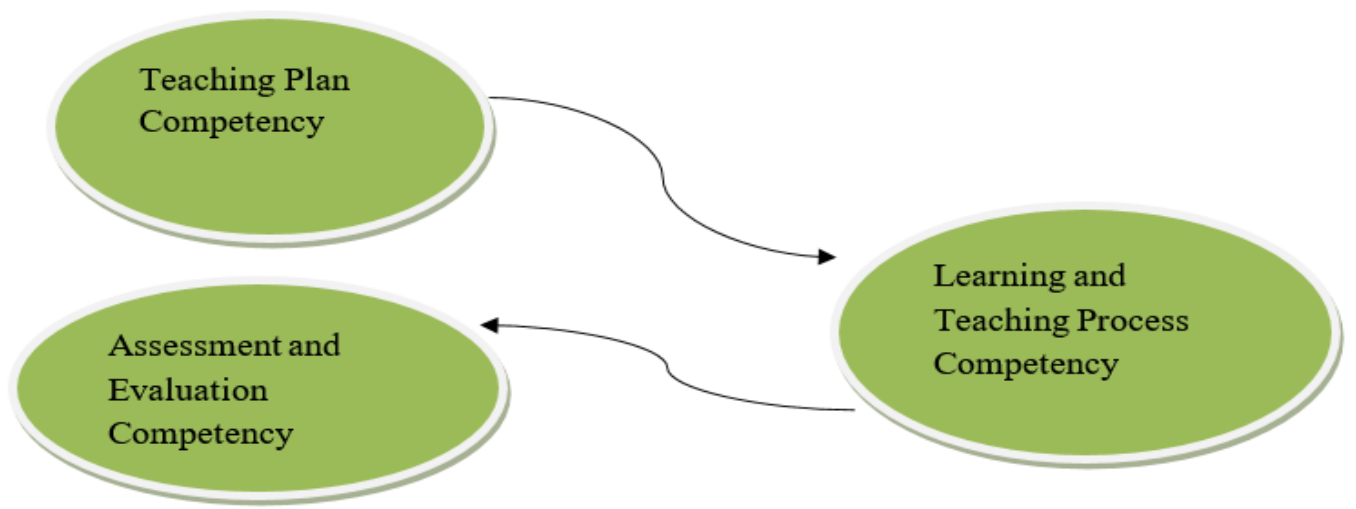




\section{RESEARCH METHOD}

The research design which was used in this research was descriptive qualitative. It was aimed to find out how the implementation and the contribution of teachers' pedagogical competence toward the effectiveness of teaching of English at MTsN Balang-Balang.

The subjects of this research were the English teachers of MTsN Balang-Balang. There were three English teachers as subjects in this research. Research instrument used in this research were observation Guide and interview guide. Data analyzed trough three steps in data analysis. They are data reduction, data display, and conclusion drawing and verification.

\section{FINDINGS AND DISCUSSION}

This part deals with the presentation of the data analysis and the discussion on the result of the research. The teachers' pedagogical competence are as follow:

\section{Teaching Plan (Preparing lesson plan)}

In obtaining data or information about the contribution of teachers' pedagogical competence of the English teacher in learning process activity, the researcher conducted the research by observing three English teachers when they were teaching in the classroom at MTsN Balang-Balang. The findings of the observation were supported by data interview of those three English teachers.

The teacher A In conducting learning process activity, the teacher came into the classroom of grade one. She conducted the learning process by passing every steps of the pedagogical competence indicator. For the teaching plan, the teacher A brought the lesson plan in the classroom and delivering the materials suitable with the lesson plan that she had made. The observation result also supported by the interview when the researcher interviewed the teacher as follow:

Before the learning activity began, does $\mathrm{Mr} / \mathrm{Mrs}$ prepare anything first? ( for example: teaching plan or reread the material)

Yes, the first thing that I do is making a teaching plan to make my activity become effective an efficient.

Is there any explanation about the objective of learning in your teaching plan?

Yes, there is the objective of learning explanation.

How do you select materials before coming to the class?

I select the material suitable with the syllabus. (interview on August $21^{\text {st }} 2015$ of English teacher who teaches at first grade)

For the teacher B who teaches at the second grade when she came into the class she brought her lesson plan, but she did not describe about the objective of the learning. For the 
reason why she did not describe the objective of the learning, the researcher interviewed the teacher as follow.

Before the learning activity began, does Mr/Mrs prepare anything first? ( for example: teaching plan or reread the material)

Sure, because the teaching plan is the guide in teaching and learning and as a teacher must be reread the material that is going to be thought before come to the class.

Is there any explanation about the objective of learning in your teaching plan?

Yes, but in 2013 curriculum there was no the objective of learning.

How do you select materials before coming to the class?

I select the material suitable with the syllabus. (interview on August $21^{\text {st }} 2015$ of English teacher who teaches at second grade). When the researcher checked her lesson plan, the result was different with the interview result. In her lesson plan still describe the objective of the learning.

While the third teacher who teaches at the third grade, when she came into the class she did not bring the lesson plan but she made the lesson plan. After the researcher observed in the classroom the researcher checked her lesson but still the same result that in her lesson plan also she described the objective of the learning. For the others indicator she did. To support the data above the researcher interviewed the teacher as follow.

Before the learning activity began, does $\mathrm{Mr} / \mathrm{Mrs}$ prepare anything first? ( for example: teaching plan or reread the material)

Yes sure. I prepare the lesson plan before teaching in the classroom and organize the materials.

Is there any explanation about the objective of learning in your teaching plan?

Yes, but in 2013 curriculum there was no the objective of learning. (interview on August $21^{\text {st }} 2015$ of English teacher who teaches at third grade)

Based on the on the observation result above shows that only the two of the three English teachers at MTsN Balang-Balang who brought their lesson plan in the classroom when they were teaching. For the teacher who teaches in second grade, based on the interview result, in her lesson plan there was no learning objective, because still use the 2013 curriculum at their school. While in the 2013 curriculum there was no learning objective.

\section{Learning and Teaching Process}

The second pedagogical competence about Learning and Teaching Process. The teacher $\mathrm{A}$ at the first indicator about opening lesson. This activity open the lesson by giving the students chance to open the lesson by reciting surah (Al-Fatiha). The second indicator delivering materials. On this activity the teacher delivers the material structured and suitable with the teaching plan. In delivering the material the teacher tells the student about the material that is going to be learned and the teacher A used a speech method in delivering the material. The third indicator using teaching media. On this indicator the teachers A prepared 
a English handbook for the students in the class. The fourth indicator using communicative language. On this indicator the teacher use a communicative language in order that, the students can understand what is the teacher being talked. This indicator also aims to invite the students to use a communicative language as well. The fifth indicator motivate the students. This activity is very important for the teacher to keep the students learning. How to invite the students to learn and keep spirit every time when learning process. The sixth indicator is organizing activities. This activity how the teacher organizes the activity to make learning process effective. In this activities the teacher A organized the activity by divided the students into couple. This activity how the students can practice the greetings and take leaving in front of the others students. The seventh activity is interacting with students communicatively. In this activity the teacher A and the students are giving the feedback for each others. The eighth indicator is concluding lessons. In this activity the teacher drawn the conclusion about the material that has been thought. The ninth indicator is providing feedback. The teacher A giving the respond about what the students asked. The tenth indicator is conducting assessment and evaluation. In the end of the learning process the teacher gave the students chance to answer all of the question about the material that has been learned and the teacher accumulate the result. The last is using time effectively. The teacher A, she used her time till the end of the learning process effectively.

Based on the observation result above conducted by the researcher, the teacher A implemented a number of pedagogical competencies in the learning process activity. They were teaching plan, teaching and learning process, and assessment. For example organizing the materials, where the students were giving a chance to a couple to talked about what is greeting and leave taking. The observation result above was supported by the interview as follow:

How do you open the class?

I open the class by giving the students perception first.

How do you deliver the material?

Explain first and than directly interact with the student.

When teaching and learning process take place, how do you use the teaching media?

Sometimes direct use the media in the class but sometimes use laptop and LCD.

How do you motivate the students in the class?

Always interact with face to face approach.

How do you respond the students' complaint or questions about the material?

Sometimes there is a students who asks the question out of the material, but always give the answer that always understood by the student. (interview on August $21^{\text {st }} 2015$ of English teacher who teaches at first grade)

For the teaching and learning competence, both of them had a different way when they were teaching. For the teacher B, in indicator about using teaching media, the teacher B 
also prepare about students' worksheet to answer all of the question about the material that being thought. In another hand, the teacher B in delivering the material she used a discussion method. Then in organizing the activity, teacher B gave the students opportunity to came forward to practiced about giving and denying instruction. In indicator about concluding the lesson the teacher B only gave the students chance to conclude about the lesson that has been thought and the students directly practice it in front of the others students. After the students explaining the conclusion the teacher $\mathrm{B}$ gave an additional explanation to make the students' conclusion perfect.

For the others indicators in this competence (teaching and learning competence), the teacher B did the same thing what the teacher A did.

Based on the observation result above conducted by the researcher, the teacher $\mathrm{B}$ implemented a number of pedagogical competencies in the learning process activity. For example gave the students worksheet to answer the class task. To support the observation result above the researcher interviewed the teacher.

How do you open the class?

I open the class by giving the students student chance to take pray together and give some apperception first.

How do you deliver the material?

Explain first and than directly interact with the student.

When teaching and learning process take place, how do you use the teaching media?

Sometimes direct use the media in the class but sometimes use laptop and LCD.

How do you motivate the students in the class?

Always interact with face to face approach.

How do you respond the students' complaint or questions about the material?

Sometimes there is a students who asks the question out of the material, but always give the answer that always understood by the student. (interview on August $21^{\text {st }} 2015$ of English teacher who teaches at second grade)

For the teaching and learning process, the teacher $\mathrm{C}$ in organizing the activity, the teacher $\mathrm{C}$ made the students in a group. In another hand, the teacher $\mathrm{C}$ in delivering the material she used a discussion method and used a laptop and LCD as a teaching media. For the indicator about concluding a lesson, teacher $\mathrm{C}$ gave them an exercise after that concluded the lesson. The data above also supported by the interview when researcher interviewed the teacher.

When teaching and learning process take place, how do you use the teaching media?

Sometimes direct use the media in the class but sometimes use laptop and LCD.

How do you respond the students' complaint or questions about the material?

By giving them a explanation and give them some example about the material. (interview on August $21^{\text {st }} 2015$ of English teacher who teaches at third grade). 
Julkifli Hidayat Ada \& St. Azisah, The Contribution of Teachers Pedagogical Competence Toward. .

Based on the observation and interview result above conducted by the researcher, the teacher $\mathrm{A}, \mathrm{B}$, and $\mathrm{C}$ implemented a number of pedagogical competencies in the learning process activity. That is way, the researcher conclude based on the observation that all the English teacher at MTsN Balang-Balang had implemented the pedagogical competency, had made the class became effective and able to motivate the students to attend the class, induce the students to learn the material as well as explain the material clearly so that the students could comprehend it easily.

\section{Assessment And Evaluation}

The third competency is Assessment and Evaluation. The teacher A at the first activity choosing questions based on the level of difficulty. The teacher $\mathrm{A}$, she chosen the question based on the material that has been thought. The second is repairing the problem is not valid. In this activity the teacher correct the wrong answer that made by the students. The third is checking the answer. After the students already done their evaluation the teacher checked the answer. The fourth indicator is classifying the results of the assessment. After checking the answer the teacher A classify the result of the evaluation of the students.

For the teacher B In this competence, all the indicators about this competency, the teacher B also do the same thing what the teacher A did. On the third competency about Assessment and Evaluation Competency, there was no difference among the three teachers. They all implemented the third competency based on the 2013 curriculum.

The researcher presents the data or information which were achieved by interviewing. It is about the teacher's pedagogical competence. In this research, the researcher interviewed three English teachers to find out their pedagogical competences' contribution when they are teaching.

The following question aimed to collect data about the contribution of English teachers' pedagogical competence when they are teaching.

How do you give the students assessment and evaluation?

Suitable with the teaching plan and syllabus and also suitable with question instrument. (interview on August 21 2015 of English teacher who teaches at first grade)

How do you give the students assessment and evaluation?

Suitable with the teaching plan and syllabus and also suitable with question instrument. (interview on August $21^{\text {st }} 2015$ of English teacher who teaches at second grade)

How do you give the students assessment and evaluation?

Suitable with the teaching plan and syllabus and also suitable with question instrument. (interview on August $21^{\text {st }} 2015$ of English teacher who teaches at third grade)

Based on the result of observations conducted by the researcher, it was found there is the contribution of their pedagogical competence when they are teaching. The teacher A, B, and $\mathrm{C}$ had conducted their learning with their pedagogical competence. During the learning activity the researcher found that they had gave their contribution toward the effectiveness 
of learning, especially in teaching English lesson. This result seen from how the learners participated in the class room and actively did the task that given by the teacher.

The pedagogical competence had gave the big influence toward the learning take place. That the pedagogical competence is very important for the effectiveness of learning. The teacher A, B, and C implemented the three main competencies of pedagogical competence. They are teaching plan, teaching and learning process, and assessment. All of them were going effective and structured so the learning become effective.

Data achieved through interviews by the research show that the English teachers of MTsN Balang-Balang had gave the contribution toward the effectiveness of teaching of English. In general in teaching English the teacher had showed their competence toward the teaching process.

\section{CONCLUSIONS AND SUGGESTIONS}

Based on the data analysis and the discussion in the previous chapter, the researcher put forward the following conclusions:

1. The teachers' pedagogical competence of English teacher at MTsN Balang-Balang could be seen from their teaching process. The teachers used the right teaching method and also could create a good study environment, and able to use the medias of learning. Guide the student and also watch the development of student. Give them evaluation and assessment.

2. The effectiveness of learning process is depend on how the pedagogical competence of teacher is able to implemented, so the learning process can running structured and effective.

3. There is always a significant contribution of teachers' pedagogical competence toward the effectiveness of teaching and learning process.

In this point, the researcher would like to give several suggestions as follows:

1. To make learning process became more effective, the teachers should have a competence whatever they are, especially pedagogical competence.

2. For the researcher and all his friends who study at English Education Department that before you come to school to teach, first of all you have to mastered yourself or you have to be more competent and have a competency as a candidate of teacher in the future.

\section{REFERENCES}

Arikunto, Suharsimi. Prosedur Penelitian: Suatu Pendekatan Praktik, Jakarta: PT Rineka Cipta, 2010).

Alim, Jauharul. Kompetensi Pedagogik Guru PAI di MTsN Winong Kabupaten Pati Tabun Ajaran 2010/2011. Retrieved on August $25^{\text {th }} 2015$ from 
Julkifli Hidayat Ada \& St. Azisah, The Contribution of Teachers Pedagogical Competence Toward. .

http://library.walisongo.ac.id/digilib/files/disk1/121/jtptiain-gdl-jauharulal-6042-1skripsi-p.pdf

Arikunto, Suharsimi, Prosedur Penelitian Suatu Pendekatan Praktik, (Jakarta: Rineka Cipta, 2006). Bridges, David. "School-based teacher education." Eds. David Bridges \& Trevor Kerry. Developing teachers professionally. London: Routledge. 1993. 51-66.

Bulajeva, Tatjana. "Teacher professional development in the context of school reform." Journal of Teacher Education and Training. 2. 2003.

Catdwell, B.J. and Spinks, J.M, The Self-Managing School, (London:RoutledgePalmer, 1988). Djamaroh, S. B, Guru dan Anak didik Dalam Interaksi Edukati, (Jakarta: Rineka Cipta, 2008). Departemen Pendidikan Nasional Republik Indonesia, Undang-Undang Republik Indonesia No 14 Tahun 2005 Tentang Guru dan Dosen, Jakarta: Biro Hukum dan Organisasi Sekertariat Jendral Departemen Pendidikan, 2005, Cet. I

Depdikbud, Kamus Besar Bahasa Indonesia edisi II. Jakarta: Balai Pustaka, 1996.

Gordon, Thomas. Guru Yang Efektif. Cara Untuk Mengatasi Kesulitan Dalam Kelas. (Jakarta:Rajawali, 1990.

Gupta, Kavita. A practical guide for need assessment. San Francisco: John Wiley \& Sons. Inc. 1999.

Hansen, Sevn-Erik. "Preparing student teachers for curriculum making." J. Curriculum Studies. 30. 2, 1998.

James, David et. al."The professional teachers." Creative professional: Learning to teach 1419 years old. Ed. D. James. Florence: Taylor \& Francis. 1998.

Kress, Gunther. A curriculum fort he future, Cambridge Journal of Education. 30.1, 2000.

Katane, Irena et al. "Teacher competence and further education as priorities for sustainable development of rural school in Latvia." Journal of Teacher Education and Training. 6. 2006.

Maharani, Ika Fitri. Kompetensi Pedagogik Guru Dalam Mendorong Motivasi Belajar siswa Pada Mata pelajaran Sejarah Kelas XI IPS SMA Negeri 5 Malang Tabun Ajaran 2011/2012. Retrieved on August 25 2015 from https://www.google.co.id/webhp?sourceid=chromeinstant\&ion=1\&espv $=2 \& i e=U T F-8 \# q=$ skripsi $+i k a+$ fitri + maharani + pdf. 2012.

Mulyasa, E. Standar Kompetensi Dan Sertifikasi Guru, (Bandung: PT. Remaja Rosda Karya, 2007)

Niemi, Hannele \& Ritva Jakku Sihvonen. "Research-based teacher education." Researchbased teacher education in Finland: Reflection by Finnish teacher educators . Eds. Sihvonen, Ritva Jakku. \& Hannele Niemi. Turku: Paionsalama Oy. 2006.

Husain, S.S. \& Asharaf, S.A. Menyongsong Keruntuban Pendidikan Islam, Terj. Rahmani Astuti, (Bandung: CV. Gema Risalah Press, 1994).

Popham, W. J. \& Baker, E.L, Tehnik Mengajar Secara Sistematis, (Jakarta: Rineka Cipta, 2005).

Selvi, Kiymet. "The English language teachers' competencies, presented paper." The Fifth International JTET Conference. Hungary: The Conference conducted at the meeting the University of. Debrecen. 2007.

Selvi, Kiymet. "Phenomenology of Lifelong Learning", Analecta Husserliana: The Yearbook 
of Phenomenological Research. Ed. Anna-Teresa Tymieniecka. Dordrecht: Springer. 2006.

Synder, K.J. and Anderson, R.H, Managing Productive Schools:Toward an Ecology, (Orlando: Academic Press College Division, 1986).

Subroto, S. Beberapa Aspek Dasar Kependidikan, (Jakarta: Bina Aksara, 1983).

Stoffels, Newton Trevor. "Sir on what page is the answer? Exploring teacher decisionmaking during complex curriculum change, with specific references to the use of learners support materials." International Journal of Educational Development. 25. 2005.

Sahid, Rahmat. Analisis data Penelitian Kualitatif Model Miles dan bubrman. Retrieved on August $25^{\text {th }} 2015$ from http://sangit26.blogspot.com/2011/07/analisis-data-penelitiankualitatif.html. 2011.

Yasin, A. Fatah. Dimensi-Dimensi Pendidikan Islam, (Malang: UIN Malang Press, 2008).

Usman, Uzer. Menjadi Guru Profesional, (Bandung: PT. Remaja Rosda Karya, 2001). 